\title{
Age, growth and mortality of Pontinus kuhlii (Bowdich, 1825) (Scorpaeniformes: Scorpaenidae) in the Gorringe, Ampère, Unicorn and Lion seamounts
}

\author{
RAFAELA BARROS PAIVA, ANA NEVES, VERA SEQUEIRA, ANA RITA VIEIRA, \\ MARIA JOSÉ COSTA, ISABEL DOMINGOS and LEONEL SERRANO GORDO
}

Centro de Oceanografia and Departamento de Biologia Animal, Faculdade de Ciências da Universidade de Lisboa, Bloco C2, Campo Grande, 1749-016 Lisboa, Portugal. E-mail: rcpaiva @fc.ul.pt

\begin{abstract}
SUMMARY: Age and growth of Pontinus kuhlii were studied using otoliths of 153 males and 148 females, with males having a greater length (and age) than females. A high level of agreement was achieved among readers. Due to gear selectivity, only ages above 7 years (males) and 8 years (females) were estimated in whole otoliths. To estimate length-at-age in younger specimens, backcalculation was also considered but its use in otoliths with ages greater than 22 years was not possible because the growth rings were too close to each other. Von Bertalanffy growth parameters were estimated by sex using each of these methods and also using an approach that combines mean length-at-age obtained from backcalculation and direct reading on the otoliths. The likelihood ratio test showed significant differences between sexes in the three approaches and Akaike's information criterion suggests that the backcalculation approach was the best one for describing $P$. kuhlii growth: $\mathrm{TL}=38.89\left[1-\mathrm{e}^{(-0.07(\mathrm{t}+1.96))}\right]$ and $\mathrm{TL}=56.50\left[1-\mathrm{e}^{(-0.04(\mathrm{t}+1.87))}\right]$ for females and males, respectively. Natural mortality estimates varied around 0.15 year $^{-1}$ and 0.07 year $^{-1}$ for females and males, while the total mortality estimated for 2011 was 0.33 year-1 for females and 0.21 year-1 $^{-1}$ for males.
\end{abstract}

Keywords: Pontinus kuhlii, offshore rockfish, whole otoliths, precision estimators, age and growth, Scorpaenidae, mortality.

RESUMEN: Edad, crecimiento y mortalidad de Pontinus Kuhli (Bowdich, 1825) (Scorpaeniformes: Scorpaenidae) en LOS MONTES SUBMARINOS DE GorRINGe, AMPÈre, Unicorn y Lion. - La edad y crecimiento de Pontinus kuhlii se ha estudiado a partir de otolitos de 153 machos y 148 hembras, alcanzando los machos una talla mayor (y edad) que las hembras. Un alto nivel de acuerdo fue alcanzado entre los lectores. Debido a la selectividad del arte de pesca, sólo las edades de más de 7 años (machos) y 8 años (hembras) pudieron ser estimadas en otolitos enteros. Para la estimación de la talla por edad en los ejemplares más jóvenes, el retrocálculo también fue considerado, pero su uso en los otolitos con edades mayores de 22 años no fue posible, ya que los anillos de crecimiento se encontraban demasiado cerca unos de los otros. Los parámetros de crecimiento, ajustados a la ecuación de Von Bertalanffy, fueron estimados por sexo con ambos métodos, y también a partir de otro que combina la talla media por grupo de edad obtenida a partir del retrocálculo y de la lectura directa en los otolitos. La prueba de máxima verosimilitud mostró diferencias significativas entre sexos en los tres métodos y el criterio Akaike de información sugiere que el retrocálculo fue el mejor para describir el crecimiento de $P$. kuhlii: TL $=38.89\left[1-\mathrm{e}^{(-0.07(t+1.96))}\right]$ y $\mathrm{TL}=56.50\left[1-\mathrm{e}^{(-0.04(\mathrm{t}+1.87))}\right]$ para las hembras y machos, respectivamente. La estimación de la mortalidad natural varió entre $0.15 \mathrm{año}^{-1}$ y $0.07 \mathrm{año}^{-1}$ para hembras y machos, mientras que la mortalidad total estimada para 2011 fue de 0.33 año ${ }^{-1}$ para las hembras y $0.21 \mathrm{año}^{-1}$ para los machos.

Palabras clave: Pontinus kuhlii, rascacio de fuera, otolitos enteros, estimadores de precisión, edad y crecimiento, Scorpaenidae, mortalidad.

\section{INTRODUCTION}

Age information is the most influential biological variable for estimating growth rate, mortality rate and productivity in fishes (Campana 2001). Fish age can usually be estimated using the periodicity of the formation of growth increments in calcified hard structures, such as scales, otoliths, fin rays and vertebrae (Wright 
et al. 2002). However, otoliths are the structures preferred by fisheries scientists because of (i) the precision of age estimates based on annuli; (ii) the relative ease of otolith preparation and annuli enumeration; (iii) the lack of reabsorption (the mineral deposited is not used again, even in periods of starvation); and (iv) the continuous growth of otoliths throughout the lifetime of the fish (Bergstad 1995, Mendonza 2006, Vieira et al. 2009). In addition to age and growth determination, otoliths have also been studied in many different fields, such as fish biology (hearing and balance in fishes), larval fish ecology, species identification, fish stock identification and environmental reconstruction of fish habitats (Mendonza 2006).

The offshore rockfish Pontinus kuhlii (Bowdich, $1825)$ is a bathydemersal scorpaenid which commonly inhabits hard bottoms in the eastern Atlantic at depths ranging from 100 to $450 \mathrm{~m}$ (Merella et al. 1998, Pais et al. 2005). It occurs in the Macaronesian Archipelagos (Azores, Madeira, Canary and Cape Verde) and on the coast of Morocco and Mauritania, but is uncommon in the Mediterranean Sea (Monteiro et al. 1991, Merella et al. 1998, López-Abellán et al. 2001). In Portuguese waters, the annual landings of offshore rockfish has reached around 300 tonnes during the last ten years (DGPA 2012), making it one of the two most important Scorpaeniformes species landed (together with the bluemouth, Helicolenus dactylopterus [Delaroche, 1809]). The species is commercially exploited by a longline fleet operating in the seamounts southwest of Portugal. Fishery resources associated with seamounts are particularly susceptible to disturbances caused by fluctuations in environmental conditions and fishing pressure (Pitcher et al. 2007). One of the reasons for this high vulnerability is related to the k-strategy (slow growth rate, high longevity, late maturity and low fecundity) (King and Mcfarlane 2003) shown by the majority of the species that occur on seamounts, making them extremely sensitive to fishing exploitation.

Knowledge of the biology of this species is scarce as only age and growth have been studied in Azorean waters (Isidro 1990, 1996, Krug et al. 1998) and Canary Island waters (López-Abellán et al. 2001). The same authors also made a comparison between whole otoliths, sectioned otoliths and scales, concluding that whole otoliths were the most appropriated structure for age reading in $P$. kuhlii. However, the periodicity of ring formation has never been validated; neither trends in growth patterns nor the consistency among readers has been assessed.

Therefore, the main goals of this paper are to provide: a) new information on ring formation, growth patterns and consistency among readers; b) new data on age and growth of the offshore rockfish from the Gorringe, Ampère, Unicorn and Lion seamounts, and c) natural mortality and total mortality estimations to obtain an initial approximation of the exploitation level for this species.

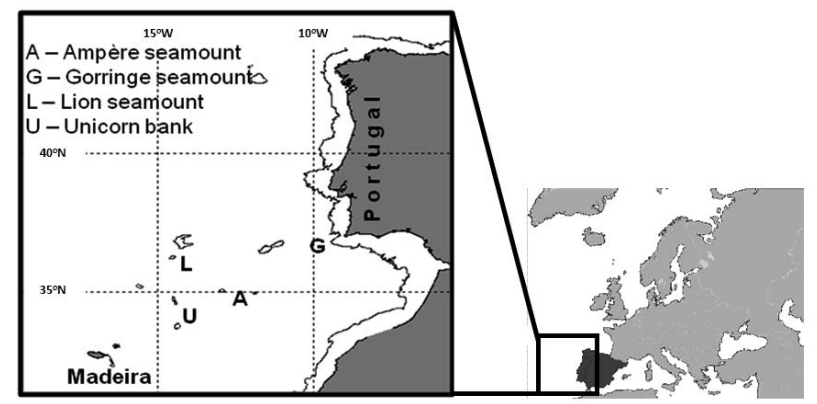

FIG. 1. - Map of the northeast Atlantic with the sampling locations.

\section{MATERIAL AND METHODS}

\section{Length-weight relationship}

A total of 444 specimens (219 males and 225 females) were obtained on a monthly basis between April 2009 and January 2012, on the Gorringe, Ampère, Unicorn and Lion seamounts (Fig. 1) at depths of around $240 \mathrm{~m}$. The total length (TL, $\pm 1 \mathrm{~mm}$ ), total weight (TW, $\pm 1 \mathrm{~g}$ ) and sex of each individual were registered. The Mann-Whitney test was applied to test the existence of significant differences between sexes according to total length. The relationship between total length and total weight was calculated using a power function $\left(\mathrm{TW}=\mathrm{aTL} \mathrm{TL}^{\mathrm{b}}\right)$ and the t-test was used to test the differences in allometric coefficients (Zar 1999).

\section{Age and growth}

The sagittal otoliths were removed, cleaned and stored dry in plastic vials. Right otoliths were immersed in a 1:1 glycerine-alcohol solution, with the sulcus acusticus placed downwards, and the posterior region was observed under a stereomicroscope using reflected light, a dark background and a magnification of $18 x$.

In age and growth, four issues were analysed: the trends in growth patterns, the consistency among readers, the marginal increment analysis (MIA), and the estimation of growth parameters.

To analyse the trends in growth patterns, a total of 219 otoliths were measured using a micrometer eyepiece and the radius and the distance between the nucleus and the successive growth increments were recorded.

To analyse the consistency among readers a subsample of 100 otoliths covering all available length classes was read by three of the authors to establish a reading and interpretation criteria, assuming birth date as 1 January (Hile 1950). Reproducibility between readers was analysed using the average percent error (APE) (Beamish and Fourier 1981), the coefficient of variation (CV) (Chang 1982) and the index of precision D (Chang 1982). A test for symmetry (Bowker 1948) was used to detected systematic differences between the ages assigned by the three readers. 
The MIA (Fowler and Short 1998) was based on 240 otoliths and used to determine whether there was an annual growth pattern. The MIA was based on individuals ranging from 19.2 to $44.5 \mathrm{~cm}$ TL. Because of the difficulty of obtaining a large number of otoliths per month, the MIA was not made by age group (as ideally should be done) but used for all ages combined.

To estimate the parameters of the von Bertalanffy growth function (VBGF) (von Bertalanffy 1938), three approaches were used: whole otolith readings, backcalculation, and a combination of both. For whole otolith readings, only males aged $>7$ years and females aged $>8$ were considered because, owing to the gear selectivity, specimens under $17 \mathrm{~cm}$ TL were not caught. To overcome this sampling difficulty, the relationship between otolith radius (OR) and TL was established by power function to back calculate the mean length-atage (Francis 1990, Folkvord et al. 2002), especially in missing length classes (the smaller sizes). Like Tuset et al. (2004), we used the standardized residuals of the regression to identify which type of estimate (biological or mathematical) should be used and to determine which age classes should be considered in the backcalculation analysis. Then, the geometric mean regression was used to calculate the mean length-at-age at lower ages. Finally, the mean length-at-age obtained by the whole otolith readings and by backcalculation was compared using the t-test (Zar 1999).

The last method is a combination of the age assigned by whole otolith reading with data obtained by backcalculation (the mean length-at-ages lower than 7 years for males and lower than 8 years for females which were the minimum ages observed in the direct reading of the otoliths). VBGF curves were fitted to length-at-age data by nonlinear regression. To choose the best approach, the Akaike information criterion (AIC) (Akaike 1973) was used. Likelihood ratio tests were used to test for differences in growth among sexes and approaches. These analyses were performed using the $\mathrm{R}$ routine stats software package (R-2.14.1 for Windows).

\section{Mortality estimates}

The instantaneous rate of natural mortality (M) was estimated using two methods: (1) Pauly's method (Pauly 1980), $\log _{10} \mathrm{M}=0.0066-0.279 \log _{10} \mathrm{~L}_{\infty}+0.6543 \log _{10} \mathrm{~K}$ $+0.4634 \log _{10} \mathrm{~T}$, where $\mathrm{L}_{\infty}$ is the asymptotic length $(\mathrm{cm})$ and $\mathrm{K}$ the Brody growth coefficient from the VBGF and $\mathrm{T}$ the mean annual seawater temperature; (2) Ralston's regression method (Ralston 1987), $\mathrm{M}=0.0189+2.06 \mathrm{~K}$, where $\mathrm{K}$ is the Brody growth coefficient.

Total instantaneous mortality rate, $\mathrm{Z}$, was estimated for the year 2011 using age catch curve analysis (Beverton and Holt 1957). Only fully recruited ages were used to estimate $\mathrm{Z}$, as the age group at the top of the catch curve may not be fully vulnerable to the fishing gear (Everhart et al. 1975). Fishing mortality (F) was estimated as $\mathrm{F}=\mathrm{Z}-\mathrm{M}$.

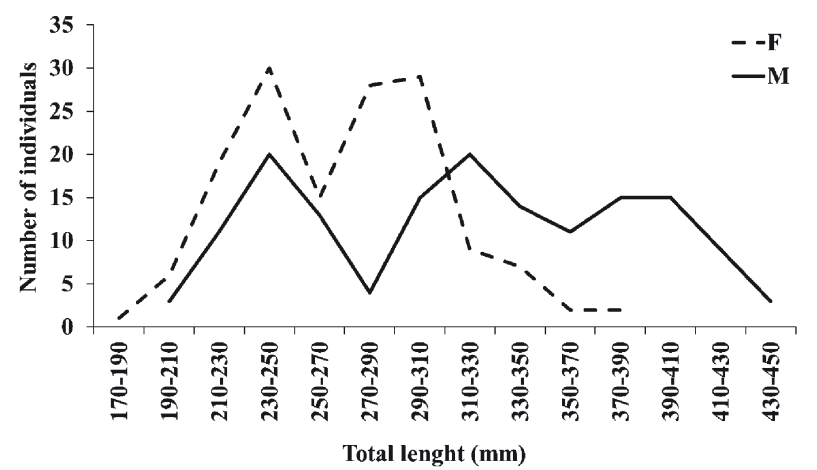

FIG. 2. - Length frequency distribution by sex for the total number of individuals analysed. (M, Males; F, Females)

\section{RESULTS}

\section{Length-weight relationship}

Males were larger than females, ranging respectively from 19.3-44.5 $\mathrm{cm}$ and 17.4-38.2 $\mathrm{cm}$ TL (Fig. 2). The Mann-Whitney test revealed significant differences between sexes, regarding TL (U=13734.00; p-level<0.05).

The relationship between total length and total weight was: $\mathrm{TW}=0.0098 \mathrm{TL}^{3.1549}, \mathrm{R}^{2}=0.9417$ for females and TW $=0.0059 \mathrm{TL}^{3.2906}, \mathrm{R}^{2}=0.9864$, for males. Females showed isometric growth $(\mathrm{t}=-0.039 ; \mathrm{p}>0.8)$ while males showed positive allometry $(\mathrm{t}=9.448$; $\mathrm{p}<<0.05)$.

\section{Age and growth}

\section{Trends in growth patterns}

In larger otoliths (particularly in specimens with a TL $>30 \mathrm{~cm}$ ) an increasing number of ramifications could be seen at the edge, adding some complexity to the process of reading. These edge difficulties were also increased by the proximity of the growth bands. On the

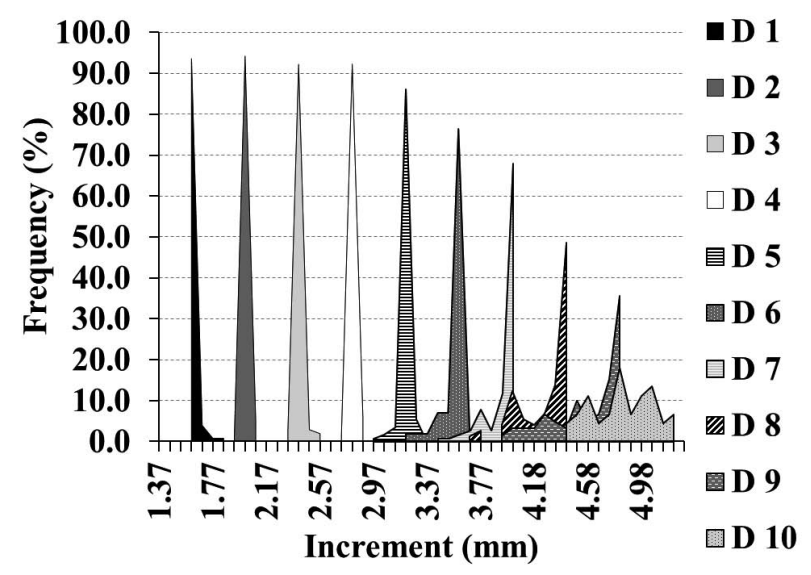

FIG. 3. - Distance (D) from nucleus to the first 10 annuli from observation on whole otoliths of Pontinus kuhlii. 
TABLE 1. - Measure of precision for age readings on Pontinus kuhlii between readers.

\begin{tabular}{lccc}
\hline Index & Reader 1 vs Reader 2 & Reader 1 vs Reader 3 & Reader 2 vs Reader 3 \\
\hline CV $(\%)$ & 1.49 & 2.16 & 2.00 \\
APE $(\%)$ & 2.53 & 3.40 & 2.16 \\
D $(\%)$ & 1.05 & 1.53 & 1.41 \\
Agreement $(\%)(0)$ & 47 & 39 & 58 \\
Agreement $(\%)(0 \pm 1)$ & 83 & 73 & 86 \\
\hline
\end{tabular}

(0) corresponding to zero differences between the ages assigned by the two readers

$(0 \pm 1)$ corresponding to $-1,0$ and 1 differences between the ages assigned by the two readers

other hand, otoliths of smaller individuals showed a clear deposition of growth bands in the first six years (with a complete individualization of the increments) and an increasing complexity afterwards (Fig. 3). The mean and standard deviation of the first 10 increments were: $1.61 \pm 0.03 \mathrm{~mm}, 2.01 \pm 0.02 \mathrm{~mm}, 2.41 \pm 0.03$ $\mathrm{mm}, 2.81 \pm 0.02 \mathrm{~mm}, 3.21 \pm 0.06 \mathrm{~mm}, 3.58 \pm 0.09 \mathrm{~mm}$, $3.96 \pm 0.13 \mathrm{~mm}, 4.27 \pm 0.19 \mathrm{~mm}, 4.59 \pm 0.26 \mathrm{~mm}$ and $4.81 \pm 0.26 \mathrm{~mm}$.

\section{Consistency among readers}

Table 1 shows the indexes of precision between readers. A high level of agreement was achieved between all readers as indicated by the lower CV, APE and $\mathrm{D}$, although the highest precision was obtained between readers 2 and 3 .

The agreement plot which compares the age assignment between readers (Fig. 4) showed the lowest variation to be that between readers 2 and 3 . Reader 2 tended to assign slightly higher ages than reader 3 , especially for specimens larger than $30 \mathrm{~cm}$ TL (Fig. 5).
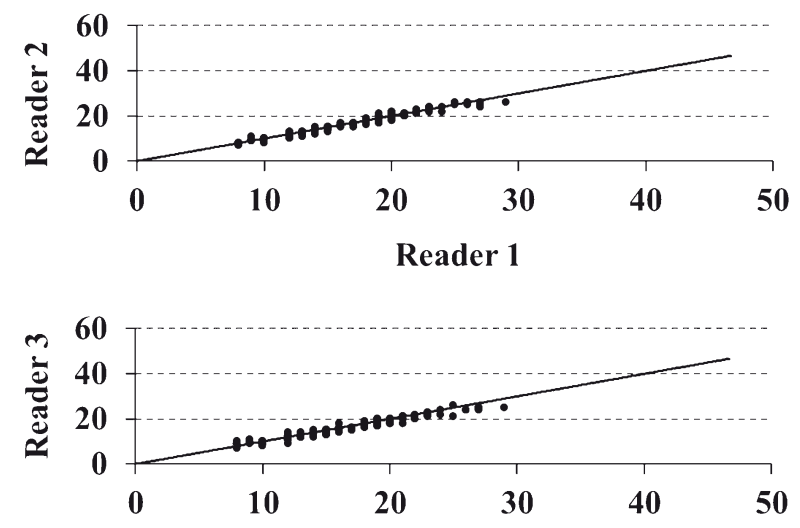

Reader 1

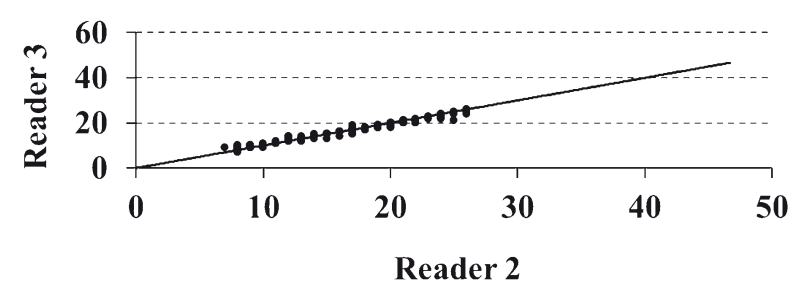

FIG. 4. - Agreement plot for comparisons between ages assigned by readers 1,2 and 3 in whole otoliths of Pontinus kuhlii.
There was no evidence of systematic disagreement between any of the readers (test of symmetry ${ }_{1-2}: \chi^{2}=37.33, \mathrm{df}=31, \mathrm{p}=0.20$; test of symmetry ${ }_{1-3}: \chi^{2}=43.73, \mathrm{df}=31, \mathrm{p}=0.06$; test of symmetry ${ }_{2-3}$ : $\chi^{2}=36.33, \mathrm{df}=27, \mathrm{p}=0.11$ ).

As a good agreement between readers was achieved, the remaining otoliths were read twice by one reader (reader 1), and estimates that did not differ in more than one year were accepted and used to assign a modal age.
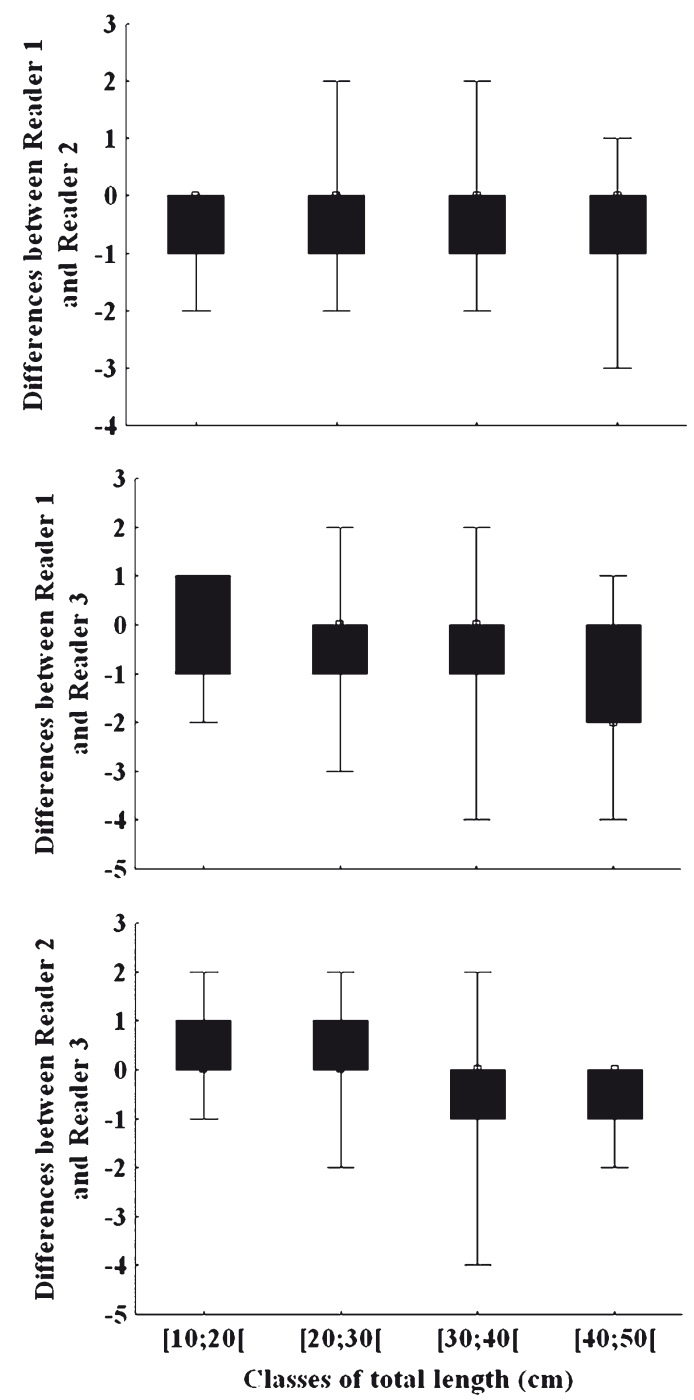

FIG. 5. - Box plot of the differences resulted from the comparisons of the age assigned by the three readers and Pontinus kuhlii total length ( $\square$ median; $\square$ 25\%-75\%; $\square$ min-max). 


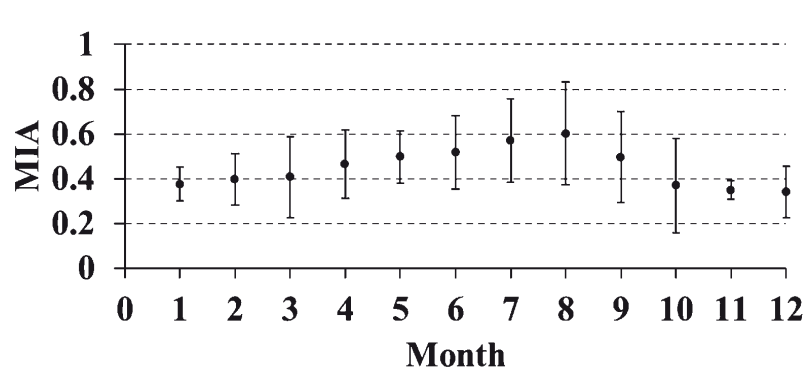

FIG. 6. - Monthly evolution of marginal increment analysis (MIA) in whole otoliths of Pontinus kuhlii.

\section{Age determination and growth comparisons}

MIA showed that there is a clear annual pattern of growth increment formation, with an increasing trend from March to August (Fig. 6). The lowest values were found between October and January, suggesting that the growth band is formed in this period.

For age determination, a total of 301 individuals were used: 153 males and 148 females. Of these, 282 otoliths were used for ageing, which means that only $6.31 \%$ of otoliths could not be read. Tables 2 and 3 present the age-length keys for males and females, respectively. The maximum age observed was 28 years $(30.0 \mathrm{~cm} \mathrm{TL})$ for females and 30 years $(44.5 \mathrm{~cm} \mathrm{TL})$ for males. Females and males with ages lower than 8 and 7 , respectively, were not present.

Regarding the backcalculation methodology, a good relationship between total length and otolith radius was obtained for both sexes (for females, $\mathrm{TL}=47.582 \mathrm{OR}^{0.9658}$ $\mathrm{r}=0.868$; for males $\mathrm{TL}=37.58 \mathrm{OR}^{1.1179} \mathrm{r}=0.945$ ). Since
A

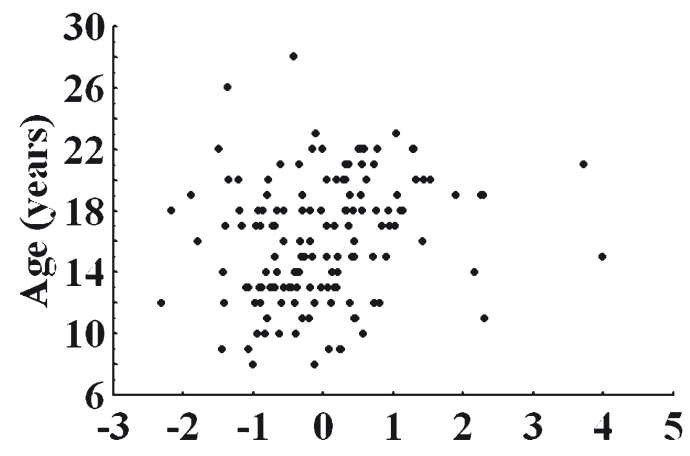

B

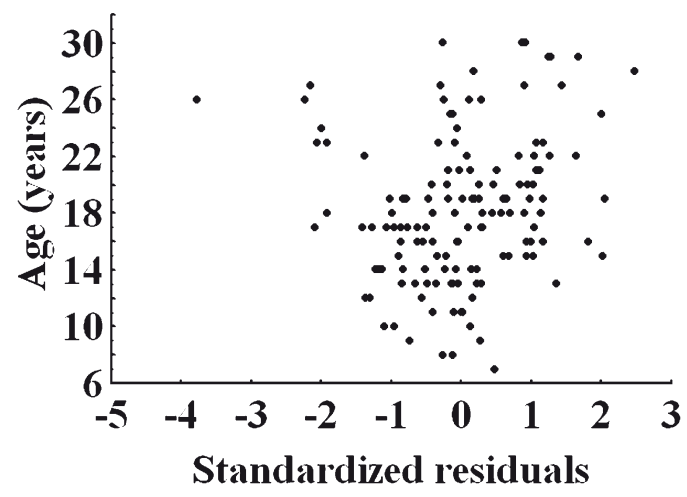

FIG. 7. - Residual plots of age fish versus otolith radius (OR) for females (A) and males (B).

the otolith growth was allometric by the 23 years age class for males and females (Fig. 7), the backcalculation was only applied until the 22 years age class. Table 4 shows the mean distance and standard deviation

TABLE 2. - Age-length (in cm) key obtained by direct reading of the otoliths in males of Pontinus kuhlii; SD, standard deviation.

\begin{tabular}{|c|c|c|c|c|c|c|c|c|c|c|c|c|c|c|c|c|c|c|c|c|c|c|c|c|c|}
\hline $\mathrm{CT}$ & 7 & 8 & 9 & 10 & 11 & 12 & 13 & 14 & 15 & 16 & 17 & 18 & 19 & 20 & 21 & 22 & 23 & 24 & 25 & 26 & 27 & 28 & 29 & 30 & Total \\
\hline $19-20$ & 1 & & & & & & & & & & & & & & & & & & & & & & & & 1 \\
\hline $20-21$ & & 2 & & & & & & & & & & & & & & & & & & & & & & & 2 \\
\hline $21-22$ & & & 2 & 3 & & & & & & & & & & & & & & & & & & & & & 5 \\
\hline $22-23$ & & & & & 1 & 2 & 2 & & & & & & & & & & & & & & & & & & 5 \\
\hline $23-24$ & & & & & 3 & 1 & 5 & 2 & & 1 & & & & & & & & & & & & & & & 12 \\
\hline $24-25$ & & & & & & & 2 & 2 & & 1 & 3 & & & & & & & & & & & & & & 8 \\
\hline $25-26$ & & & & & & 1 & 1 & 2 & & & & & & & & & & & & & & & & & 4 \\
\hline $26-27$ & & & & & & & & 1 & 2 & 3 & 2 & & & & & & & & & & & & & & 8 \\
\hline $27-28$ & & & & & & & & 1 & & & 1 & 1 & & & & & & & & & & & & & 3 \\
\hline $28-29$ & & & & & & & & & & & 1 & & & & & & & & & & & & & & 1 \\
\hline $29-30$ & & & & & & & 1 & & 3 & 1 & 1 & 3 & & & & & & & & & & & & & 9 \\
\hline $30-31$ & & & & & & & & & 2 & 1 & 2 & & & 1 & & & & & & & & & & & 6 \\
\hline $31-32$ & & & & & & & & & 1 & & 1 & 2 & 4 & & & 1 & & & & & & & & & 10 \\
\hline $32-33$ & & & & & & & & 1 & & 1 & 2 & 2 & & 1 & & & & & & & & & & & 7 \\
\hline $33-34$ & & & & & & & & & & 1 & & & 2 & 1 & 1 & 1 & 1 & & & & & & & & 7 \\
\hline $34-35$ & & & & & & & & & & 1 & & & 3 & 2 & 1 & & & & & & & & & & 7 \\
\hline $35-36$ & & & & & & & & & & & & & 1 & & & 1 & & & & & & & & & 2 \\
\hline $36-37$ & & & & & & & & & & & & 2 & 1 & & 1 & & 2 & & & & & 1 & & & 7 \\
\hline $37-38$ & & & & & & & & & & & & & 3 & 1 & 1 & & 1 & & & 1 & & & & & 7 \\
\hline $38-39$ & & & & & & & & & & & & 1 & & 1 & 1 & 1 & & 1 & & & 1 & & & 1 & 7 \\
\hline $39-40$ & & & & & & & & & & & & & & & 1 & & 2 & 1 & 1 & 1 & & & & & 6 \\
\hline $40-41$ & & & & & & & & & & & & & & & & 1 & & & 1 & 2 & 2 & & 1 & & 7 \\
\hline $41-42$ & & & & & & & & & & & & & & & & 1 & & & & & 2 & 1 & 1 & 1 & 6 \\
\hline $42-43$ & & & & & & & & & & & & & & & & & & & & & & & 1 & & 1 \\
\hline $43-44$ & & & & & & & & & & & & & & & & & & & 1 & & & & & & 1 \\
\hline $44-45$ & & & & & & & & & & & & & & & & & & & & & & & & 1 & 1 \\
\hline
\end{tabular}

$\begin{array}{lllllllllllllllllllllllllll}\text { Total } & 1 & 2 & 2 & 3 & 4 & 4 & 11 & 9 & 8 & 10 & 13 & 11 & 14 & 7 & 6 & 6 & 6 & 2 & 3 & 4 & 5 & 2 & 3 & 3 & 140\end{array}$

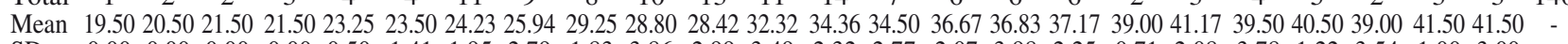
$\begin{array}{llllllllllllllllllllllllll}\text { SD } & 0.00 & 0.00 & 0.00 & 0.00 & 0.50 & 1.41 & 1.95 & 2.79 & 1.83 & 3.86 & 2.99 & 3.49 & 2.32 & 2.77 & 2.07 & 3.98 & 2.25 & 0.71 & 2.08 & 3.78 & 1.22 & 3.54 & 1.00 & 3.00 & -\end{array}$ 
$100 \cdot$ R.B. PAIVA et al.

TABLE 3. - Age-length (in cm) key obtained by direct reading of the otoliths in females of Pontinus kuhlii; SD, standard deviation.

\begin{tabular}{|c|c|c|c|c|c|c|c|c|c|c|c|c|c|c|c|c|c|c|c|c|c|c|}
\hline $\mathrm{CT}$ & 8 & 9 & 10 & 11 & 12 & 13 & 14 & 15 & 16 & 17 & 18 & 19 & 20 & 21 & 22 & 23 & 24 & 25 & 26 & 27 & 28 & Total \\
\hline $17-18$ & 1 & & & & & & & & & & & & & & & & & & & & & 1 \\
\hline $18-19$ & & & & & & & & & & & & & & & & & & & & & & 0 \\
\hline $19-20$ & 1 & 2 & 2 & & & & & & & & & & & & & & & & & & & 5 \\
\hline $20-21$ & & & & & & & & & & & & & & & & & & & & & & 0 \\
\hline $21-22$ & & 1 & 2 & 1 & 1 & 1 & & & & & & & & & & & & & & & & 6 \\
\hline $22-23$ & & 1 & & 2 & 5 & 3 & 1 & & & 1 & & & & & & & & & & & & 13 \\
\hline $23-24$ & & 1 & 1 & 2 & 5 & 7 & 5 & 1 & & & & & & & & & & & & & & 22 \\
\hline $24-25$ & & & & & & 1 & & 2 & 2 & 2 & 1 & & & & & & & & & & & 8 \\
\hline $25-26$ & & & & & & 2 & 1 & & 1 & 1 & & & & & & & & & & & & 5 \\
\hline $26-27$ & & & & 1 & & 2 & 1 & 2 & & 1 & 2 & 1 & & & & & & & & & & 10 \\
\hline $27-28$ & & & & & & & & 2 & & 3 & 2 & & 1 & & & & & & & & & 8 \\
\hline $28-29$ & & & & & & & & 1 & 2 & 3 & 4 & 2 & & 1 & 4 & & & & & & & 17 \\
\hline $29-30$ & & & & & & & & 2 & & & 6 & 2 & 1 & & 1 & 1 & & & & & & 13 \\
\hline $30-31$ & & & & & & & 1 & 1 & 1 & 1 & 2 & 1 & 4 & 3 & 1 & & & & & & 1 & 16 \\
\hline $31-32$ & & & & & & & & & & 1 & & 1 & 2 & 1 & & & & & & & & 5 \\
\hline $32-33$ & & & & & & & & & & & & & 1 & & 1 & 1 & & & & & & 3 \\
\hline $33-34$ & & & & & & & & & & & & 2 & & 2 & 1 & & & & 1 & & & 6 \\
\hline $34-35$ & & & & & & & & & & & & & & & & & & & & & & 0 \\
\hline $35-36$ & & & & & & & & & & & & & 1 & & 1 & & & & & & & 2 \\
\hline $36-37$ & & & & & & & & & & & & & & & & & & & & & & 0 \\
\hline $37-38$ & & & & & & & & 1 & & & & & & & & & & & & & & 1 \\
\hline $38-39$ & & & & & & & & & & & & & 1 & & & & & & & & & 1 \\
\hline $39-40$ & & & & & & & & & & & & & & & & & & & & & & 0 \\
\hline $40-41$ & & & & & & & & & & & & & & & & & & & & & & 0 \\
\hline Total & 2 & 5 & 5 & 6 & 11 & 16 & 9 & 12 & 6 & 13 & 17 & 9 & 11 & 7 & 9 & 2 & 0 & 0 & 1 & 0 & 1 & 142 \\
\hline Mean & 18.50 & 21.30 & 21.10 & 23.332 & 22.86 & 23.88 & 24.72 & 28.00 & 27.00 & 27.19 & 28.50 & 30.17 & 31.68 & 31.21 & 30.61 & 31.0 & - & - & 33.5 & - & 30.5 & - \\
\hline SD & 1.41 & 1.76 & 1.67 & 1.72 & 0.67 & 1.45 & 2.49 & 3.71 & 2.51 & 2.61 & 1.58 & 2.35 & 3.28 & 1.94 & 2.62 & 2.12 & - & - & 0.00 & - & 0.00 & - \\
\hline
\end{tabular}

between the nucleus and the first 22 growth increments obtained by backcalculation for males and females. Comparing the mean length-at-age obtained by whole otolith readings and backcalculation (Table 5), significant differences were obtained in a few age classes for females but in a larger number for males.

Table 6 presents the VB (von Bertalanffy) growth parameters obtained from the three approaches used. The likelihood ratio test $(\mathrm{p}<0.05)$ showed significant differences between sexes for the three approaches (whole otolith readings: $\chi^{2}=58.59, \mathrm{df}=3$; backcalculation: $\chi^{2}=72.54, \mathrm{df}=3$; combined: $\left.\chi^{2}=80.88, \mathrm{df}=3\right)$. The
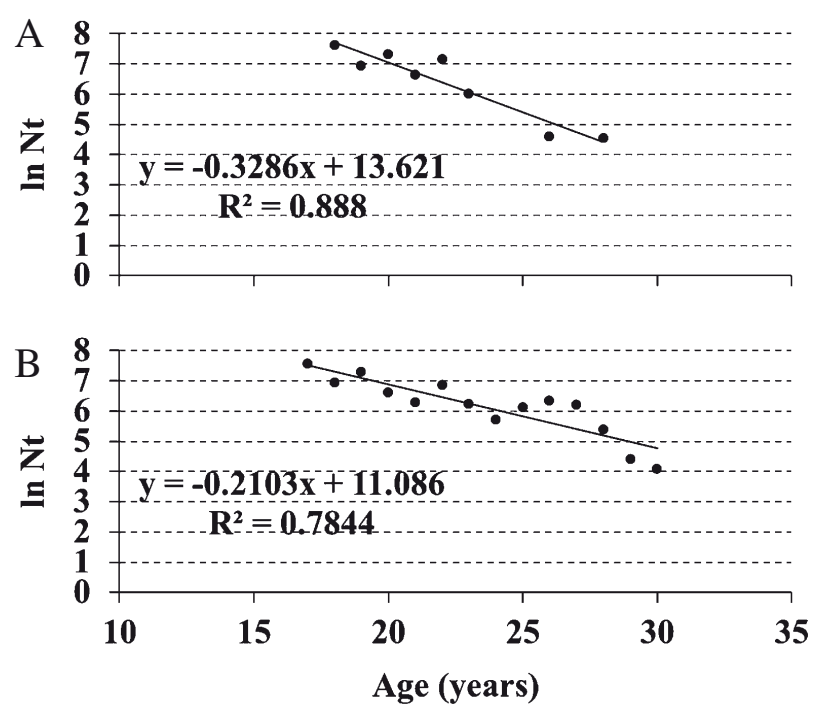

FIG. 8. - Catch curve based on 2011 data for females (A) and males (B).
AIC values suggest that the backcalculation approach was the best one to describe $P$. kuhlii growth because it showed the best fit to the data (Table 6).

\section{Mortality estimates}

Mortality (M) estimates varied according to the method used. Estimates of $\mathrm{M}$ assume constant natural mortality for all age classes. Natural mortality in the offshore rockfish was estimated as 0.13 year $^{-1}$ and 0.06 year $^{-1}$ for females and males, respectively according to Pauly's equation, using the mixture growth parameters and a mean seawater temperature of $18^{\circ} \mathrm{C}$. When the Ralston regression method was applied, natural mortality increased by 0.16 year $^{-1}$ and 0.08 year $^{-1}$ for females and males, respectively.

Offshore rockfish were fully recruited to the fishery by the ages 17 and 18 years, for females and males, respectively (Fig. 8). $\mathrm{Z}$ estimate was 0.33 year $^{-1}$ for females and 0.21 year $^{-1}$ for males. This means that $F$ is still low, varying between 0.17 and 0.20 year $^{-1}$ and between 0.13 and 0.15 year $^{-1}$, respectively in females and males.

\section{DISCUSSION}

\section{Length-weight relationship}

P. kuhlii shows sexual dimorphism, with males attaining a higher length and consequently a higher weight, which explains the positive allometry found in the males' length-weight relationship. In the present study, for specimens with TL>39 cm, only males were 
TABLE 4. - Mean distance and standard deviation (in $\mathrm{mm}$ ) between the nucleus and the first 22 growth increments (D) for males and females of Pontinus kuhlii.

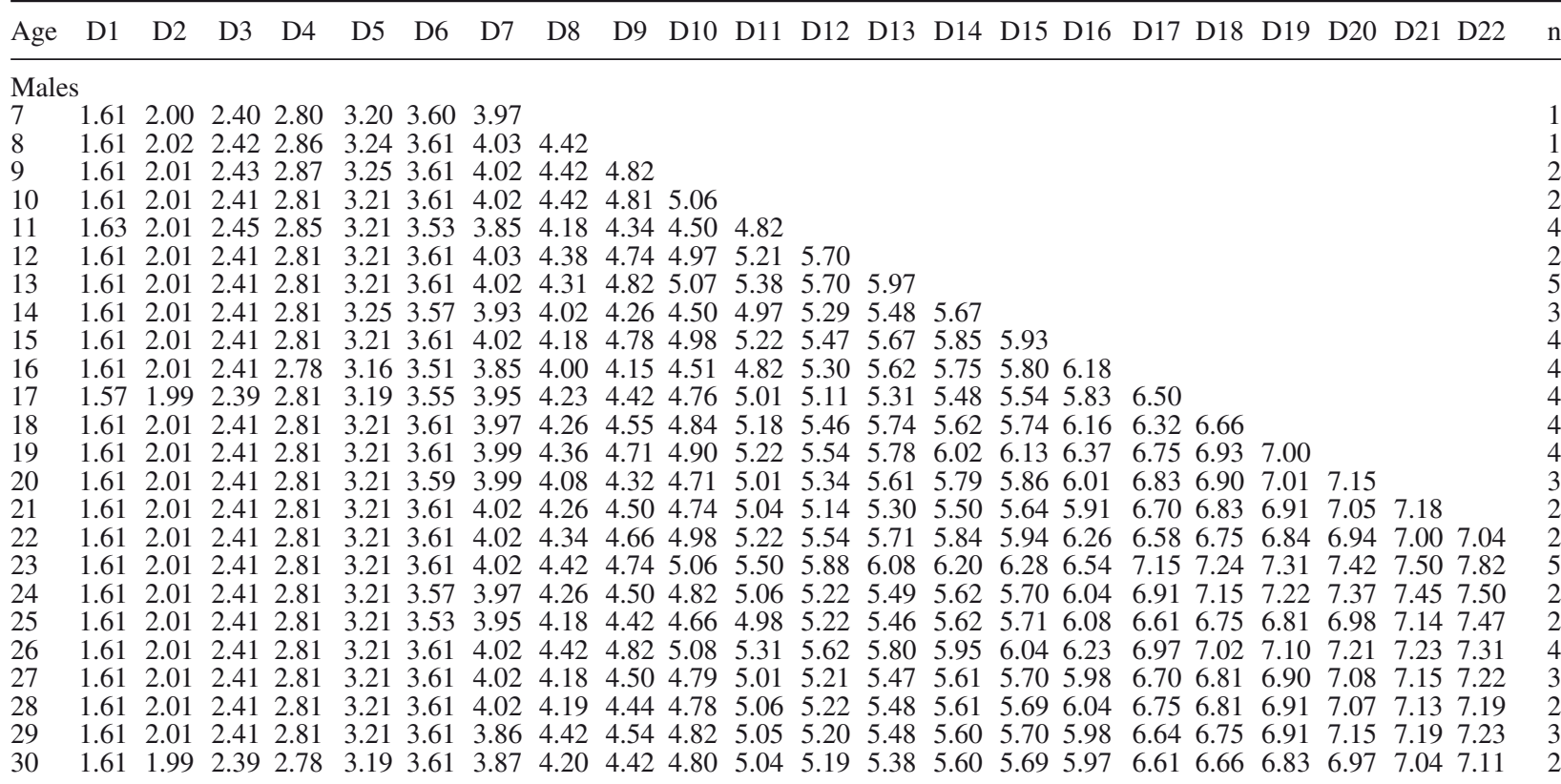

$\begin{array}{lllllllllllllllllllllll}\text { Mean } 1.61 & 2.01 & 2.41 & 2.81 & 3.21 & 3.59 & 3.98 & 4.26 & 4.56 & 4.82 & 5.10 & 5.39 & 5.60 & 5.73 & 5.82 & 6.11 & 6.71 & 6.87 & 6.98 & 7.13 & 7.20 & 7.32\end{array}$ $\begin{array}{lllllllllllllllllllllll}\text { SD } & 0.01 & 0.01 & 0.01 & 0.02 & 0.02 & 0.03 & 0.06 & 0.13 & 0.20 & 0.18 & 0.17 & 0.22 & 0.22 & 0.19 & 0.20 & 0.19 & 0.21 & 0.18 & 0.16 & 0.16 & 0.16 & 0.24\end{array}$

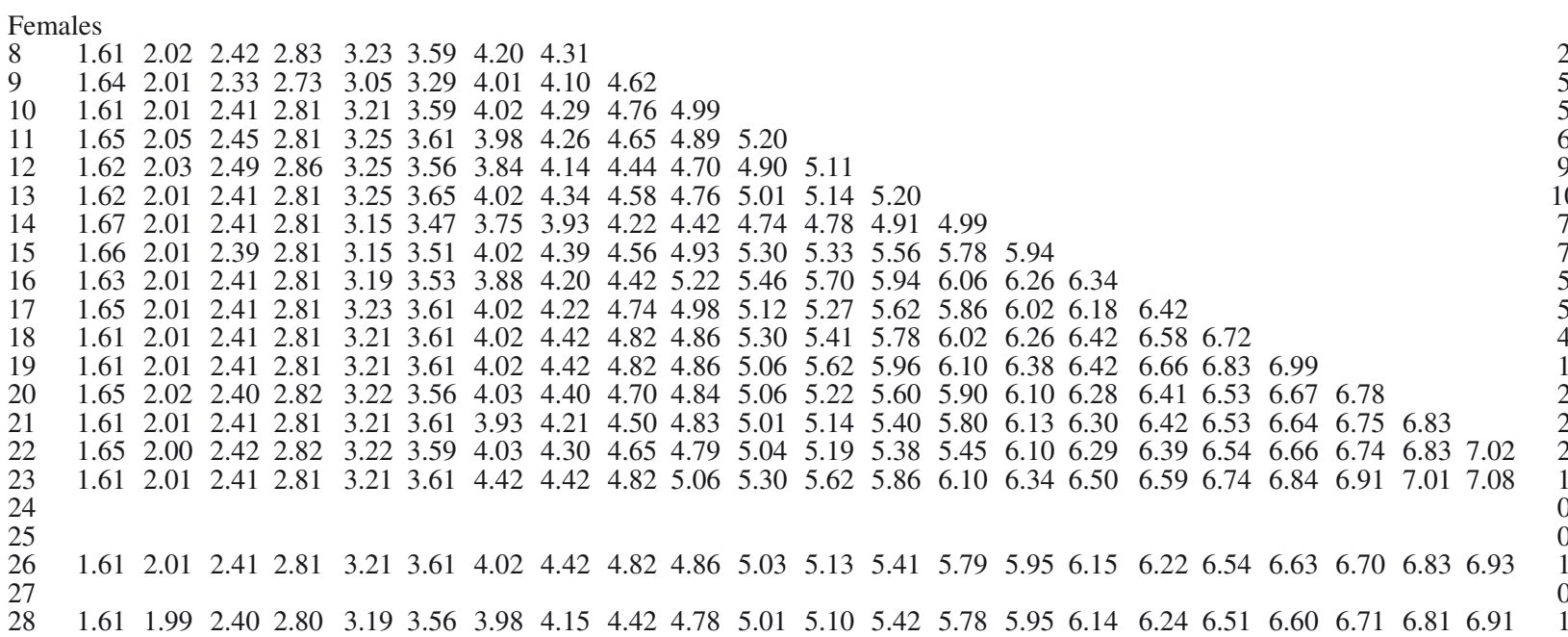

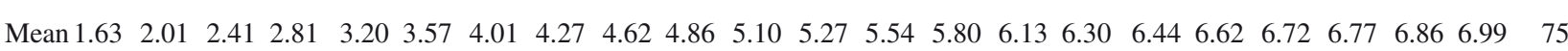
$\begin{array}{lllllllllllllllllllllllll}\text { SD } & 0.02 & 0.01 & 0.03 & 0.02 & 0.05 & 0.08 & 0.14 & 0.14 & 0.17 & 0.17 & 0.18 & 0.24 & 0.30 & 0.30 & 0.16 & 0.12 & 0.15 & 0.12 & 0.14 & 0.08 & 0.08 & 0.08\end{array}$

caught. This pattern was also reported by Estácio et al. (2001), who observed a prevalence of males in larger length classes, and by López-Abellán et al. (2001), who determined a maximum length of $46.0 \mathrm{~cm}$ TL for males and $38.0 \mathrm{~cm}$ TL for females, which is very similar to the values obtained in the present study.

\section{Age and growth}

In the present study the posterior region of whole otoliths was the region analysed, because it provided a better distance of the growth increments leading to a better individualization between them. $P$. kuhlii otoliths showed a larger individualization of at least the first six growth increments, a finding which may be related to the age of first maturity. In fact, it is known that after maturation occurs, the available energy must be channelled first to the reproductive effort and second to growth, leading to shorter growth increments in the forthcoming years (Wootton 1992).

To minimize the error associated with the subjectivity of age estimation, readings were compared among three readers for whole otoliths. We followed LópezAbellán et al. (2001), who compared whole and sec- 
102 - R.B. PAIVA et al.

TABLE 5. - Comparison between mean sizes (mean TL) obtained by otolith reading and backcalculation of Pontinus kuhlii. $(\alpha=0.05$, $*=\mathrm{P}<0.05 ; \mathrm{NS}$, non-significant)

\begin{tabular}{|c|c|c|c|c|}
\hline & Age & $\begin{array}{c}\text { Mean TL }(\mathrm{cm}) \\
\text { (by otolith reading) }\end{array}$ & $\begin{array}{c}\text { Mean TL }(\mathrm{cm}) \\
\text { (by backcalculation) }\end{array}$ & Significance \\
\hline \multirow[t]{15}{*}{ Females } & 8 & 18.50 & 19.33 & NS \\
\hline & 9 & 21.30 & 20.85 & NS \\
\hline & 10 & 21.10 & 21.90 & NS \\
\hline & 11 & 23.33 & 22.95 & NS \\
\hline & 12 & 22.86 & 23.68 & $*$ \\
\hline & 13 & 23.88 & 24.87 & $*$ \\
\hline & 14 & 24.72 & 26.00 & NS \\
\hline & 15 & 28.00 & 27.42 & NS \\
\hline & 16 & 27.00 & 28.16 & NS \\
\hline & 17 & 27.19 & 28.74 & $*$ \\
\hline & 18 & 28.50 & 29.51 & $*$ \\
\hline & 19 & 30.17 & 29.95 & NS \\
\hline & 20 & 31.68 & 30.15 & NS \\
\hline & 21 & 31.21 & 30.57 & NS \\
\hline & 22 & 30.61 & 31.10 & NS \\
\hline \multirow[t]{16}{*}{ Males } & 7 & 19.50 & 17.58 & $*$ \\
\hline & 8 & 20.50 & 19.01 & $*$ \\
\hline & 9 & 21.50 & 20.47 & $*$ \\
\hline & 10 & 21.50 & 21.83 & $*$ \\
\hline & 11 & 23.25 & 23.25 & NS \\
\hline & 12 & 23.50 & 24.69 & NS \\
\hline & 13 & 24.23 & 25.79 & $*$ \\
\hline & 14 & 25.94 & 26.43 & NS \\
\hline & 15 & 29.25 & 26.91 & $*$ \\
\hline & 16 & 28.80 & 28.40 & NS \\
\hline & 17 & 28.42 & 31.59 & $*$ \\
\hline & 18 & 32.32 & 32.38 & NS \\
\hline & 19 & 34.36 & 32.98 & $*$ \\
\hline & 20 & 34.50 & 33.76 & NS \\
\hline & 21 & 36.67 & 34.15 & $*$ \\
\hline & 22 & 36.83 & 34.79 & NS \\
\hline
\end{tabular}

tioned otolith readings and concluded that the former were more suitable for ageing offshore rockfish, as sectioned otoliths lose growth increments in the major axis because of the edge ramifications. The highprecision indices found in the present study also suggest that whole otoliths are suitable for age and growth studies for this species. In addition to precision, whole otoliths can be more easily obtained and do not involve expensive and long analysis processes. The ranges of the precision estimates calculated for the three readers were well below the average values reported in the literature (Campana 2001).

In the present study only $6.31 \%$ of otoliths could not be read but $36 \%$ of otoliths were found to be very difficult to read or unreadable by Isidro (1996). This means that otolith reading easiness and growth pattern may be influenced by the intrinsic physiologic fish behaviour and environmental characteristics of the water masses where fish live.

The results of the present study suggest that $P$. kuhlii is a long-lived species with maximum ages and lengths similar to those reported by Isidro (1996) for Azorean waters. This author reported a maximum age/ length of 29 years and $40.5 \mathrm{~cm}$ TL for females, and 32 years and $49.5 \mathrm{~cm}$ TL for males. These maximum ages are higher than those reported for Canary Island waters (14 years and $38 \mathrm{~cm}$ TL, for females; 18 years

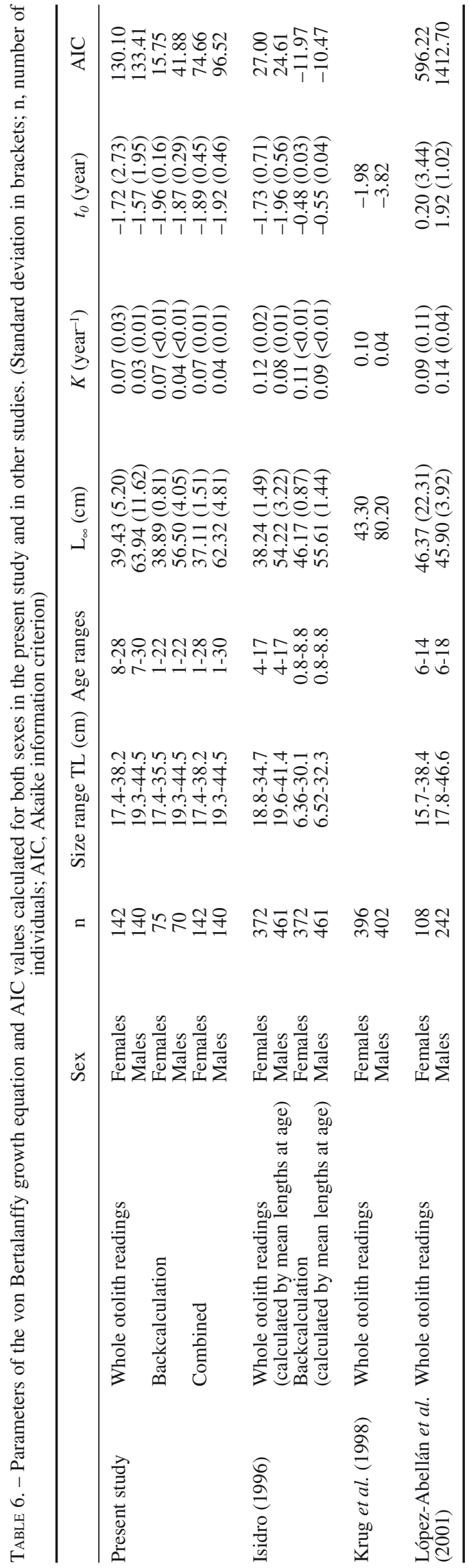


TABLE 7. - Likelihood ratio test between the von Bertalanffy growth parameters obtained in the present study with those obtained by other authors $(\alpha=0.05, *=P<0.05)$.

\begin{tabular}{lccc}
\hline Comparisons & Sex & $\chi^{2}$ & Significance \\
\hline Present study (whole otolith readings) vs & $\mathrm{F}$ & 54.11 & 3 \\
López-Abellán et al. (2001) (whole otolith readings) & $\mathrm{M}$ & 92.42 & 3 \\
& & $\mathrm{~F}$ & 89.05 \\
Present study (whole otolith readings) vs & $\mathrm{M}$ & 107.08 & 3 \\
Isidro (1996) (whole otolith readings) & $\mathrm{F}$ & 69.59 & 3 \\
Present study (backcalculation) vs & $\mathrm{M}$ & 142.78 & 3 \\
Isidro (1996) (backcalculation) & $*$ & $*$ \\
\hline
\end{tabular}

and $42 \mathrm{~cm}$ TL, for males) (López-Abellán et al. 2001), although in the latter a probable systematic error in the interpretation of rings/false-rings might have led to an underestimation in whole otolith readings.

Concerning the three approaches used for estimating the VB growth parameters, the whole otolith readings provided good results but the lack of young age classes did not allow the best model adjustment. The combined method provided better results than the previous approach but the backcalculation showed to be the best approach for estimating the growth of the offshore rockfish. The same methodology has already been applied to describe the most appropriate growth fitting of $P$. khulli off the Azorean waters (Isidro 1996). Table 6 presents the VB growth parameters obtained by other authors and Table 7 presents the likelihood ratio test results between the VB growth parameters obtained in the present study and those obtained by other authors. Data from Krug et al. (1998) were not included in this comparison since no data were presented to allow the appliance of the likelihood ratio test. Considering the whole otolith readings approach, significant differences were obtained in both sexes and with both Azorean (Isidro 1996) and Canary Island waters (López-Abellán et al. 2001). Regarding the backcalculation approach, significant differences were also obtained in both sexes between the results of the current work and those reported by Isidro (1996).

These differences may be caused by differences in the otolith pattern identification used by the laboratories. To overcome this problem, an otolith exchange programme should be implemented by all the laboratories involved in this fishery. Also, the differences in the environmental/habitat characteristics of each study area may help to explain the differences found in the growth pattern between the seamounts studied in the current work and those from Azorean and Canary Island waters.

\section{Mortality estimates}

The determination of growth and mortality rates of important commercial species is especially critical for understanding their population dynamics and developing an appreciation of their yield potentials (Ralston and Williams 1988). Although no data are yet available to estimate the yield potential of the offshore rockfish inhabiting the Gorringe, Ampère, Unicorn and Lion seamounts, we believe that the estimated fishing mortaliy indicates that the species is still facing a low exploitation rate. Three reasons may help to explain this. One is the fact that this species is exploited on the Gorringe, Ampère, Unicorn and Lion seamounts by a fairly small longline fishery fleet (seven vessels) that also targets the swordfish, Xiphias gladius Linnaeus 1758. Actually, it is during the period of least abundance of swordfish (mainly between April and August), or when the price is considered to be low, that the fleet moves their fishing effort to the species inhabiting the seamounts, mainly the wreckfish (Polyprion americanus (Bloch and Schneider, 1801)), the blackspot seabream (Pagellus bogaraveo (Brünnich, 1768)), the alfonsinos (Beryx spp.), the conger eel (Conger conger (Linnaeus, 1758)), the forkbeard (Phycis phycis (Linnaeus, 1766)) and the offshore rockfish. The second reason is a gear selectivity effect due to the use of large hooks that reduce the size of the population fully exploited by the fishery (fish older than 17 years), as shown by the landing length composition with the absence or low representation of individuals smaller than 17 and $25 \mathrm{~cm}$ TL, respectively. Finally, weather conditions do not favour long fishing periods as the artisanal vessels that constitute this fishery cannot face the severe weather conditions that usually occur in the area.

\section{ACKNOWLEDGEMENTS}

We would like to thank the crews of the commercial vessels Porto Dinheiro, Jamaica and Augusto Alberto for their support in providing the offshore rockfish specimens used in this work. This study was partially supported by the PROMAR project 31-03-05FEP-8 "Planos de gestão e medidas de minimização de capturas acessórias e rejeições na pescaria de palangre do banco Gorringe". Rafaela Barros Paiva, Vera Sequeira and Ana Rita Vieira were funded by grants from the Fundação para a Ciência e a Tecnologia: SFRH/ BD/80268/2011, SFRH/BPD/70200/2010 and SFRH/ $\mathrm{BD} / 73506 / 2010$.

\section{REFERENCES}

Akaike H. 1973. Information theory and an extension of the maximum likelihood principle. In Petrov B.N., Csaki F. (eds), 2nd International Symposium on Information Theory. Budapest, Akadémiai Kiadó, pp. 267-281.

Beamish R.J., Fourier D.A. 1981. A method for comparing the pre- 
cision of a set of age determinations. Can. J. Fish. Aquat. Sci. 38: 982-983.

Bergstad O.A. 1995. Age determination of deep-water fishes: experiences, status and challenges for the future. In: Hopper A.G. (eds), Deep-water Fisheries of the North Atlantic Oceanic Slope. Kluwer Academic Publishers, Dordrecht, pp. 267-283.

Beverton R.J.H., Holt S.J. 1957. On the dynamics of exploited fish populations. Fish. Invest. Minist. Agric. Fish. Food 19: 1-533.

Bowker A.H. 1948. A test for symmetry in contingency tables. $J$. Am. Stat. Assoc. 43: 572-574.

Campana S.E. 2001. Accuracy, precision and quality control in age determination, including a review of the use and abuse of age validation methods. J. Fish. Biol. 59: 197-242.

Chang W.Y.B. 1982. A statistical method for evaluating the reproducibility of age determination. Can. J. Fish. Aquat. Sci. 39: 1208-1210.

Estácio S., Mendonça A., Krug H., Menezes G.M., Pinho M.R. 2001. Aspects of the reproduction of six exploited demersal fish species in the Azores archipelago. Archipélago. Life Mar. Sci. Supplement 2 (Part B): 83-94.

Everhart W.H., Eipper A.W., Youngs W.D. 1975. Principles of fishery science. Cornell Univ. Press, Ithaca, N.Y. pp. 288.

DGPA. 2012. Direcção-Geral das Pescas e Aquicultura: Publicações de Estatística da Pesca.

Folkvord A., Mosegaard H. 2002. Growth and growth analysis. In: Panfili J., Pontual H., Troadec H., Wright P. (eds), Manual of Fish Sclerochronology. Brest, France. Ifremer-IRD coedition, pp. 146-166.

Fowler A.J., Short. D.A. 1998. Validation of age determination from otoliths of the King George whiting Sillaginodes punctata (Perciformes). Mar. Biol. 130: 577-587.

Francis R.I.C.C. 1990. Back-calculation of fish length: a critical review. J. Fish Biol. 36: 883-902.

Hile R. 1950. A monograph for the computation of the growth of fish from scale measurements. Trans. Am. Fish. Soc. 78: 156-162.

Isidro E.J. 1990. Reproduction of two commercial rockfish species from the Azores (Helicolenus dactylopterus and Pontinus kuhlii). Abstracts of the First Congress on Oceanography and Marine Resources in the Central-East Atlantic: 27B.

Isidro E.J. 1996. Biology and population dynamics of selected demersal fish species of the Azores archipelago. $\mathrm{PhD}$ thesis, University of Liverpool, $249 \mathrm{pp}$.

King J.R., Mcfarlane G.A. 2003. Marine fish life history strategies: applications to fishery management. Fish. Manag. Ecol. 10: 249-264.

Krug H., Rosa D., Meneses G., Pinho M. 1998. Age and growth of some demersal species of the Azores. ICES Doc C.M., 1998/O:84: $11 \mathrm{pp}$.

López-Abellán L.J., Santamaría M.T.G., Conesa P. 2001. Age and growth of Pontinus kuhlii (Bowdich, 1825) in the Canary Islands. Sci. Mar. 65(4): 259-267.

Mendonza R.P.R. 2006. Otoliths and their applications in fishery science. Ribarstvo 64: 89-102.

Merella P., Alemany F., Grau A. 1998. New data on the occurence of Pontinus kuhlii (Bowdich, 1825) (Osteichthyes: Scorpaenidae) in the western Mediterranean. Sci. Mar. 62(1-2): 177-179.

Monteiro L.R., Isidro E.J., Lopes H.D. 1991. Mercury content in relation to sex, size, age and growth in two scorpionfish (Helicolenus dactylopterus and Pontinus kuhlii) from Azorean waters. Water, Air, Soil Pollut. 56: 359-367.

Pais A., Chessa L.A., Delrio G. 2005. Northernmost occurrence of the offshore rockfish, Pontinus kuhlii (Scorpaeniformes: Scorpaenidae), in the Mediterranean Sea. Acta Ichthyol. Piscat. 35(2): 143-145.

Pauly D. 1980. On the interrelationships between natural mortality, growth parameters and mean environmental temperature in 175 fish stocks. J. Cons. Int. Explor. Mer 39(3): 179-192.

Pitcher T.J., Morato T., Hart P.J.B., Clark M.R., Haggan N., Santos R.S. 2007. Seamounts: Ecology, Fisheries and Conservation. Fish and Aquatic Resources Series, Blackwell Publishing, 527 pp.

Ralston S. 1987. Mortality rates of snappers and groupers. In: Polovina J.J., Ralston S. (eds), Tropical Snappers and Groupers: Biology and Fisheries Management. Westview Press, Boulder, CO, pp. 375-404.

Ralston S.V., Williams H.A. 1988. Depth distributions, growth, and mortality of deep slope fishes from the Mariana Archipelago. NOAA-TM-NMFS-SWFC 113: 1-54.

Tuset V.M., González, J.I., Lozano I.J., García-Días M.M. 2004. Age and growth of the backtail comber, Serranus atricauda (serranidae), off the Canary Islands (Central-Eastern Atlantic). Bull. Mar. Sci. 74(1): 53-68.

Vieira A.R., Farias I., Figueiredo I., Neves A., Morales-Nin B., Sequeira V., Martins M.R., Gordo L.S. 2009. Age and growth of black scabbardfish (Aphanopus carbo Lowe, 1839) in the Southern NE Atlantic. Sci. Mar. 73S2: 33-46.

von Bertalanffy L. 1938. A quantitative theory of organic growth (inquires of growth laws II). Hum. Biol. 10: 181-213.

Wootton R.J. 1992. Constraints in the evolution of fish life histories. Neth. J. Zool. 42: 291-303.

Wright P.J., Panfili J., Morales-Nin B., Geffen A.J. 2002. Types of calcified structures. In: Panfili J., Pontual H., Troadec H., Wright P.J. (eds), Manual of Fish Scleochronology. Brest, France: Ifremer-IRD Coedition, pp. 29-88.

Zar J.H., 1999. Biostatistical analysis. Prentice Hall, NY, 662 pp.

Scient. ed.: F. Maynou.

Received April 4, 2012. Accepted November 8, 2012.

Published online January 28, 2013. 